\title{
Pengelolaan Pembelajaran Fisika Berbasis Masalah di SMA Negeri 1 Soromandi
}

\author{
Ikhwan \\ email: $\underline{\text { khwan puterasoromandi@yahoo.com }}$ \\ Dosen pada STAI Al-Amin Dompu
}

\begin{abstract}
Abstrak: Penelitian ini bertujuan umum tentang pengelolaan pembelajaran fisika berdasarkan masalah disekolah SMA Negeri 1 Soromandi. Tujuan khusus penelitian, yaitu mendiskripsikan tentang (1)Pengelolaan ruang dan media pembelajaran Fisika berbasis masalah dalam rangka untuk meningkatan hasil belajar siswa (2) Pengembangan materi ajar fisika berbasis masalah (3) Pelaksanaan interaksi pembelajan fisika berbasis masalah (4)Perencanaan evaluasi dan tindaklanjut pembelajaran Fisika berbasis masalah. Penelitian ini menggunakan penelitian kualitatif dengan pendekatan fenomenologi. Tekhnik pengumpulan data melalui wawancara mendalam, observasi, dan dokumentasi. Tekhnik analisis data dilakukan dengan menggunakan beberapa tahap yaitu pengumpulan data, reduksi data, penyajian data, dan verivikasi data. Hasil penelitian dan solusi; (1)Manajeme pengelolaan ruang dan media pembelajaran fisika berbasis masalah sesuai dengan kebutuhan belajar siswa sehingga pembelajran tersebut dapat memeperkaya makna baik bagi guru, siswa dan sekolah pada umunya(2) Pengembangan materi ajar fisika berbasis masalah yang harus di perhatikan adalah prosedur pengembangan bahan ajar, mengidentifikasi perilaku awal siswa, membuat perumusan tujuan pembelajaran, persiapan dan perancangan(3) Pelaksanaan interaksi pembelajaran fisika berbasis masalah, siswa dituntut untuk saling bekerjasama dalam memecahkan masalah (4) Perencanaan evaluasi dan tindakan pembelajaran fisika berbasis masalah, guru melibatkan siswa secara aktif, sehingga siswa dapat memahami informasi yang diberikan oleh guru, siswa dapat menemukan hubungan informasi baru dengan informasi yang sudah dipelajari, sehingga pada akhirnya siswa dapat memahami informasi yang berikan oleh guru dalam memahami dan mempelajari materi pengajaran berikutnya.
\end{abstract}

Kata Kunci: Pengelolaan, Fisika, Pembelajaran berbasis masalah

\section{Pendahuluan}

Kualitas pendidikan merupakan salah satu masalah nasional bahkan menjadi bahan perdebatan publik terkait kualitas pendidikan yang sering 
terjadi perubahan disegala bidang. Hal ini sejalan dengan keberadaan masyarakat, dimana sekolah dituntut untuk mempertanggungjawabkan tugasnya. Dengan kata lain pendidikan dan pembelajaran disekolah dituntut untuk melaksanakan pembelajaran yang efektif, efisien dan mengikuti arah perkembanga zaman.

Di dalam hidup ini salah satu aktivitas dasar bagi manusia adalah memecahkan masalah. Berdasarkan kenyataan, sebagian besar kehidupan manusia selalu berhubungan dengan masalah-masalah, dan kita perlu mencari penyelesaian dari masalah-masalah tersebut. Jika kita gagal menyelesaikan suatu masalah dengan cara tertentu, maka kita perlu mencoba memecahkanya dengan cara lain.

Proses pembelajaran adalah hal yang sangat penting di dalam prosespendidikan. Banyak hal yang harus diperhatikan oleh guru untuk memilih modeldan metode yang akan diterapkan dalam proses pembelajaran di kelas yaitukarakteristik materi, karakteristik siswa, sarana dan prasarana serta kemampuanguru dalam menerapkan model dan metode pembelajaran yang digunakan. Modeldan metode yang dipilih harus disesuaikan dengan materi pokok, adakalanyamateri yang berbeda harus disampaikan dengan cara yang berbeda pula. Karakteristik siswa juga mempengaruhi dalam memilih model dan metode, karakteritik siswa SMP/ SMA cenderung memiliki tingkat kemampuan berpikir yang rendah dan pola pikir yang sederhana sehingga perlu dibimbing secara bertahap untuk meningkatkan kemampuan berpikirnya. Model pembelajaran berbasis masalah sesuai untuk melatih kemampuan siswa dalam berpikir dan mengembangkan keterampilan pemecahan masalah terutama dalam pembelajaran Ilmu Pengetahuan Alam (IPA) atau sains.

Proses belajar mengajar, guru harus merangsang siswa sedemikian rupa, agar; (1) siswa mampu mengeluarkan kemampuannya, (2) siswa mampu meyerap pengetahuan yang diberikan oleh guru, (3) sikap siswa dapat tercermin sesuai dengan harapan, (4) siswa mampu mengekspor bakanya secara optimal, (5) siswa mampu memahami menggunkan pelajaran dan mampu memecahkan masalah pelajaran dengan menggunakan pemikirannya, dan (6) siswa mampu mengeluarkan pendapat atau memperlihatkan pemikiran, Rusdiana, (2016:12).

Untuk memcapai tujuan pembelajaran yang diinginkan, pada dasarnya ilmu pengetahuan sudah terserak dialam dan lingkungan sekitar, tinggal bagaimana peserta didik atau pembelajaran berekspolarasi, menggali dan menemukan, kemudian untuk memperoleh pengetahuan serta pembelajaran yang bermakna, Sugiyono (2011:9).

Pembelajaran berbasis masalah. Guru merupakan ujung tombak keberhasilan kegiatan pembelajaran disekolah yang terlibat langsung dalam merencanakan dan melaksankan kegaiatan pembelajaran. Kualitas kegiatan pembelajaran yang dilakuakan sangat bergantung pada perencanaan dan pelaksanaan proses pembelajaran yang dilakukan oleh guru. Tugas guru bukan semata-mata mengajar tapi lebih pada pembelajaran siswa. Belajar pada hakikatnya adalah proses interaksi terhadap semua situasi dan kondisi yang ada disekitar individu siswa. Belajar dapat dipandang sebagai 
proses yang diarahkan kepada tujuan dan proses melihat, mengamati, dan memahami sesuatu yang ada disekitar siswa. Kegiatan pembelajaran berbasis masalah, yang dituntut bagaimana siswa dapat berpikir kritis dalam memecahkan suatu masalah nyata.

Pembelajaran berbasis Masalah adalah pendekatan pembelajaran berbasis penyelidikan di mana siswa bekerja dalam kelompok-kelompok kecil untuk memecahkan masalah tersebut, yang didefinisikan sebagai masalah tanpa solusi yang jelas atau solusi jalan. Pembelajaran berbasis masalah mengajar dan belajar strategi yang menggunakan stimulus bermasalah sebagai sarana memotivasi siswa dan mengarahkan untuk mengembangkan dan memperoleh pengetahuan baru.

Pemecahan masalah dilakukan dengan menggunakan pendekatan berpikir secara ilmiah. Berpikir dengan menggunakan metode ilmiah adalah prose berpikir deduktif dan induktif. Proses berpikir ini dilakukan secara sistematis dan empiris. Sistematis artinya berpikir ilmiah dilakukan melalui tahapan-tahapan tertentu. Sedangkan empiris artinya prose penyelesaian masalah didasarkan pada data dan fakta yang jelas, Ari Sulistiani (2014:1).

Untuk memcapai tujuan pembelajaran yang diinginkan, pada dasarnya ilmu pengetahuan sudah terserak dialam dan lingkungan sekitar, tinggal bagaimana peserta didik atau pembelajaran berekspolarasi, menggali dan menemukan, kemudian untuk memperoleh pengetahuan serta pembelajaran yang bermakna, Sugiyono (2011:9).

Pembelajaran yang diidentik dengan kata mengajar yang berasal dari kata dasar ajar yang berarti petunujuk yang diberikan kepada seseorang supaya diketahui (diturut) ditambah dengan awalan pe dan akhiran an menjadi pembelajaran, yang berarti proses, perbuatan, cara mengajar atau mengajarkan sehingga anak didik mau belajar. Menurut Hamalik (2002) pembelajaran adalah suatu kombinasi yang tersusun meliputi unsur-unsur manusiawi (siswa dan guru), materi (buku,papan tulis, kapur dan alat belajar), fasilitas (ruang, kelas. Audio, visual), dan proses yang saling mempengaruhi mencapai tujuan pembelajaran. Pembelajaran bertujuan membantu siswa agar memperoleh berbagai pengalaman dan dengan pengalaman itu tingkah laku siswa yang meliputi pengetahuan, keterampilan, dan nilai atau norma yang berfungsi sebagai pengendali sikap dan perilaku siswa menjadi bertambah, baik secara kuantitas maupun kualitasnya.

Menurut jodion Siburian, dkk dalam panduan Materi Pembelajaran Model Pembelajaran Sains (2010:174) sebagai berikut: Pembelajaran berbasis masalah (problem bassed learning) merupakan salah satu model pembelajaran yang berorientasi dengan pembelajaran kontekstual. Pembelajaran artinya dihadapankan pada suatu masalah, yang kemudian dengan melalui pemecahan masalah, melalui masalah tersebut siswa belajar keterampilan-keterampilan yang lebih mendasar.

Menurut Muslimin I dalam Boud dan Felleti (2000:7). Pembelajaran berdasarkan masalah (problem bassed learning) adalah suatu pendekatan untuk membelajarkan siswa untuk mengembangkan keterampilan berfikir dan keterampilan memecahakan masalah, belajar peranan dewasa yang 
otentik serja menjadi pelajar yang mandiri. Pembelajaran berdasarkan masalah dirancang untuk membantu guru memberikan informasi yang sebanyak-banyaknya kepada siswa, akan tetapi pembelajaran berbasis masalah (problem bassed learning) dikembangkan untuk membantu siswa mengemabangkan kemampuan berpikir, pemecahan masalah dan keterampilan intelektual, belajar berbagai perang dewasa melalui pelibatan mereka dalam pengalaman nyata dan menjadi pembelajaran yang mandiri.

Eveline Siregar(2010:120-121) pendekatan berbasis masalah adalah suatu lingkungan belajar dimana masalah mengendalikan proses belajar mengajar. Hal ini berarti sebelum pelajar belajar, terlebih dahulu mereka diberikan umpan berupa masalah. Masalah diajukan agar pelajar mengetahui bahwa mereka memecahkan masalah tersebut.

Model ini bercirikan penggunaan masalah kehidupan nyata sehingga suatu yang harus dipelajari siswa untuk melatih dan meningkatkan keterampilan berpikir kritis dan memecahkan masalah, serta mendapatkan pengetahuan konsep-konsep penting. Dalam pendekatan pembelajaran ini mengutamakan proses belajar, dimana tugas guru harus menfokuskan diri untuk membantu siswa, mencapai keterampilan mengarahkan diri. Pembelajaran berbasis masalah penggunaanya di dalam tingkat berpikir yang lebih tinggi, dalam situasi berorientasi pada masalah, termasuk bagaimana belajar (dalam Abbas: 2000:12).

Guru dalam model ini berperan sebagai penyaji masalah, penanya, mengadakan dialog, membantu menemukan masalah, dan pemberi fasilitas pembelajaran selain itu, guru memberikan dukungan yang dapat meningkatkan pertumbuhan inkuiri dan intelektual siswa. Model ini hanya dapat terjadi jika guru dapat menciptakan lingkungan kelas yang terbuka dan membimbing pertukaran gagasan. Pembelajaran ini juga dapat meningkatkan pertumbuhan dan perkembangan aktivitas belajar siswa, baik secara individu maupun secara kelompok (dalam Abbas, 2000:12).

Polya (Abbas, 2000:18), pemecahana masalah merupakan usaha mencari jalan keluar dari suatu kesulitan untuk mencapai suatu tujuan yang tidak segera dicapai. Ada 4 yang dapat di lakukan dalam memecahkan suatu masalah yaitu; (1) memahami masalah/merumuskan masalah, (2) membuat suatu rencana ( 3) melaksanakan rencana tersebut, (4) memeriksa kembali hasil yang telah diperoleh. Dalam menerapkan model pemecahan masalah pada siswa, guru perlu mempertimbangkan tujuan dasar pemechan masalah dalam fisika yaitu; (a) pemecahanmaslah memberikan peluang kepada siswa untuk menemukan konsep fisika yang sedang dipelajari dengan strategi mereka sendiri, dan (b) dapat masalah yang dapat dipecahkan dengan berbagai cara, sehingga sering terjadi bahwa sebuah masalah memiliki lebih dari satu jawaban benar. Berdasarkan hal itulah pendekatan pemecahan masalah mendorong siswa untuk berpikir lebih dalam dan dapat menerapkan keterampilan dasar yang dimiliki masing-masing siswa.

Sukariyanto (dalam Abbas, 2000:20) menyatakan bahwa pengajaran pemecahan masalah merupakan tindakan guru dalam mendorong siswa agar menerima tantangan pertanyaan bersifat menantang, dan 
mengarahkan siswa agar dapat memecahkan masalah hendaknya memperhatikan hal-hal berikut; (a) Memahami cara siswa memecahkan masalah, (b) Mempuyai keyakinan siswa telah memiliki kemampuan prasyarat yang diperlukan dalam pemecahan masalah, (c) Memberikan kebebasan kepada siswa dalam mengungkapkan ide dan contoh-contoh sebagai pemikiran berdasarkan intuisi, dan (d) Menyadari bahwa siswa sebagai individu mempunyai kemapuan yang berbeda dalam memecahkan masalah.

Rianto (2007:69-70) Secara umum langkah-langkah model pembelajaran ini adalah: (a) Menyadari Masalah. Dimulai dengan kesadaran akan masalah yang harus dipecahkan. Kemampuan yang harus dicapai peserta didik adalah peserta didik dapat menentukan atau menangkap kesenjangan yang dirasakan oleh manusia dan lingkungan sosial, (b) Merumuskan Masalah. Rumusan masalah berhubungan dengan kejelasan dan kesamaan persepsi tentang masalah dan berkaitan dengan data-data yang harus dikumpulkan. Diharapkan peserta didik dapat menentukan prioritas masalah, (c) Merumuskan Hipotesis. peserta didik diharapkan dapat menentukan sebab akibat dari masalah yang ingin diselesaikan dan dapat menentukan berbagai kemungkinan penyelesaian masalah, (d) Mengumpulkan Data. peserta didik didorong untuk mengumpulkan data yang relevan. Kemampuan yang diharapkan adalah peserta didik dapat mengumpulkan data dan memetakan serta menyajikan dalam berbagai tampilan sehingga sudah dipahami, (e) Menguji Hipotesis. Peserta didik diharapkan memiliki kecakapan menelaah dan membahas untuk melihat hubungan dengan masalah yang diuji, (f) Menetukan Pilihan Penyelesaian. Kecakapan memilih alternatif penyelesaian yang memungkinkan dapat dilakukan serta dapat memperhitungkan kemungkinan yang dapat terjadi sehubungan dengan alternatif yang dipilihnya.

Penelitian ini mendeskripsikan tentang pengelolaan pembelajaran Fisika Berbasis Masalah di SMA Negeri 1 Soromandi yang terdiri dari, Pengelolaan ruang dan media pembelajaran Fisika berbasis masalah, Pengembangan materi ajar fisika berbasis masalah, Pelaksanaan interaksi pembelajaran fisika berbasis masala, dan Perencanaan evaluasi dan tindaklanjut pembelajaran Fisika berbasis masalah.

\section{Metode Penelitian}

Penelitian ini menggunakan metode penelitian kualitatif dengan pendekatan fenomenologi.Tujuan penelitian Mengidentifikasi pengelolaan ruang dan media pembelajaran fisika berbasis masalah, Pengembangan materi ajar fisika berbasis masalah, Pelaksanaan interaksi pembelajaran fisika berbasis masalah, dan Perencanaan evaluasi dan tindaklanjut pembelajaran fisika berbasis masalah. Teknik pengumpulan data melalui wawancara mendalam, observasi, dan dokumentasi. Wawancara mendalam dilakukan kepada kepala sekolah, wakasek. Guru dan siswa. Observasi yang dilakukan peneliti dengan masuk dan mengikuti pembelajaran di kelas maupun di luar kelas serta mengamati lingkungan sekolah. Dokumentasi dilakukan untuk mendapatkan data yang bersifat dokumenter seperti visi, 
misi, profil, perangkat perencanaan pembelajaran, RKH, RKM Promes, Prota, dan foto-foto pembelajaran. Tekhnik analisis data dilakukan dengan pengumpulan data, reduksi data, penyajian data, verivikasi data. Pengajuan keabsahan data dilakukan dengan menggunakan triangulasi sumber dan membercbeck.

\section{Pembahasan}

\section{A. Pengelolaan ruang dan media pembelajaran Fisika berbasis masalah.}

Pengelolaan pembelajaran berbasis masalah dapat berfungsi sabagai sarana komunikasi dalam menggambarkan proses Pembelajaran artinya dalam pembelajaran ini tidak mengharapkan peserta didik hanya sekedar mendengarkan, mencatat kemudian menghafal materi pelajaran, akan tetapi melalui strategi pembelajaran berbasis masalah peserta didik aktif berpikir, berkomunikasi, mencari dan mengolah data dan akhirnya menyimpulkannya. Guru dapat menerapkan pembelajaran berbasis masalah dengan mempersiapkan ruang kelas yang baik sedemikian rupa sehinggga pada saat proses pembelajaran terasa nyaman untuk melakukan pembelajaran, sekaligus guru dapat mempersiapakan media pembelajaran sesuai dengan materi yang akan diajarkan saat itu, sehingga dapat mampu mencapai tujuan yang telah direncanakan dari awal pembelajaran tersebut.

Satoru Takahashi, Eisuke Saito (2015) dalam penelitianya tentang Unraveling the process and meaning of problem-based learning experiencesmenyatakan, bahwa Pembelajaran berbasis masalah, bukan hanya dapat meningkatkan daya berpikir siswa akan tetapi pembelajaran berbasisi masalah siswa dapat mengevaluasi diri yang tinggi, perasaan atau internal yang aspek peserta didik daripada rekan-rekan kognitif dan sosial. Kemudian, di luar pengetahuan, disisi lain siswa dapat memperoleh perolehan keterampilan, pembelajaran berbasis masalah dapat memperluas perspektif peserta didik dan mempromosikan pengembangan pribadi mereka. Dalam hal ini, pembelajaran berbasis masalah dapat didefinisikan lagi, dari sudut berbeda dari penelitian sebelumnya, sebagai pembelajaran yang dapat menghasilkan emosi yang kaya dan beragam di didik secara bersamaan karena mereka menghadapi masalah, memungkinkan mereka untuk memperoleh pengetahuan materi pelajaran dan keterampilan relasional melalui dialog, dan akhirnya membimbing mereka ke ambang transformasi pribadi dalam memecahkan masalah.

Dalam ungkapan J. Contin Educ Nurs (2017) dalam penelitianya tentang Using Problem-Based Learning in Staff Development: Strategies for Teaching Registered Nurses and New Graduate Nurses. Hasil penelitiannya menunjukan bahwa pembelajaran berbasis masalah, dapat digambarkan sebagai strategi mengajar aktif, menyediakan kerangka kerja untuk pengembangan diri diarahkan belajar, evaluasi diri, komunikasi interpersonal, berpikir kritis, dan akses dan pengambilan informasi. Metode pengajaran ini dapat dimodifikasi untuk menyesuaikan hampir semua situasi. Pembelajaran berbasis masalah memberikan kesempatan untuk secara aktif terlibat dalam memecahkan masalah. 


\section{B. Pengembangan materi ajar fisika berbasis masalah.}

Pengembangan materi ajar fisika berbasis masalah sangat perlu dilaksanakan oleh guru fisika yang melalui dari penyusunan rencana mengajar sehingga pada proses pembelajaran bisa secara urut dan berkesinambungan, sehingga dalam pembelajaran evektif untuk memenuhi kebutuhan belajar siswa, pengembangan materi ajar fisika berbasis masalah hal ini dikondisikan dengan kemampuan siswa dalam memahami materi ajar tersebut.

Pengelolaan materi ajar fisika berbasis masalah melalui pembelajaran berbasis masalah dapat dicirikan pada kemampuan guru dalam mengelola materi ajar fisika bersama siswa, dalam memecahkan masalah guru dapat melibatkan siswa secara aktif dan mengajak untuk berpikir memecahkan masalah. Guru memberikan kesempatan kepada siswa untuk bekerjasama anatara satu dengan yang lainya, dan yang paling sering dilakukan adalah siswa diberikan kerjain tugas-soal yang dimana dalam mengerjakan tugas tersebut saling berjasama/kelompok. Siswa dituntut untuk saling berkomunikasi dan atau menanyakan apa yang menjadi kesulitan dalam pembelajar. Bekerjasama memberikan masalah tidak difokuskan pada masalah mata pelajaran akan tetapi siswa bisa diajarkan untuk berdialog dan untuk mengembangkan keterampilan sosial dan keterampilan berpikir siswa.

Hasil penelitian Ward, Stephen, \& Lee (2016) tentang A Revium of Research on Project-Based Learning, menyatakan bahwa pembelajaran berbasis masalah sebagai pilihan lain efektif untuk menyajikan isi pelajaran, sesekali menambah masalah di dalam kelas akan menambah variasi untuk pengalaman siswa sambil belajar, mempertahankan integritas pembelajaran. Pada saat yang sama, pengenalan bertahap masalah akan memungkinkan waktu guru untuk mengembangkan bahan-bahan baru dan belajar keterampilan baru secara optimal.

Pembelajaran fisika berbasismasalah bersifatotentik yaitu masalah berdasarkan dan diambil dari kehidupan sehari-hari, sesuai dengan pengalaman siswa dan sesuai dengan prinsip-prinsip akademik. Materi jelas, yaitu masalah dirumuskan dengan jelas, dalam arti tidak menimbulkan masalah baru bagi siswa yang pada akhirnya menyulitkan penyelesain siswa. Menurut David O, Sullivan and Finn Krewer (2016) dalam penelitianya tentang Structured Approach to Project Based Learning using a new type of Learning Management System, menyimpulkan bahawaPembelajaran berbasis masalah merupakan pembelajaran dapat meningkatkan hasil belajar dan menyediakan lingkungan belajar yang menarik untuk melibatkan siswa. Pengelolaan pembelajaran berbasisi masalah adalah cara siswa untuk berlatih pengetahuan domain tertentu melalui proyek-proyek, untuk menyempurnakan kemampuan kreativitas mereka dan untuk mewujudkan motivasi mereka dalam mengejar pengakuan akademik yang sesuai. Pengajaran melalui PBL, terutama di lingkungan kelas besar dalam pendidikan tinggi, dapat menjadi tantangan yang signifikan agak mereda melalui penggunaan sistem manajemen pembelajaran. 


\section{Interaksi pembelajan fisika berbasis masala.}

Kegiatan mengelola interaksi belajar mengajar terlebih dahulu guru harus memiliki 2 (dua) modal dasar dalam mengelola interaksi diantara lain, (1) Mampu mendesain program dan (2) Keterampilan mengomunikasikan program tersebut kepada siswa. Tidak itu pula didalam mengelola kegiatan belajar mengajar, didalam kehidupan sehari-hari penting antara guru dan siswa untuk mengkomunikasikan sesuatu hal yang terjadi baik dilingkungan sekolah maupun diluar sekolah dan interaksi tersebut harus lebih dominan antara guru dan siswa. Dalam kegiatan interaksi antara guru dan siswa/murid tentu dalam rangka mentransfer ilmu pengetahuan dan juga untuk mentransfer nilai-nilai yang akan senantiasa untuk mengelola komponen-konponen yang ada dan salin berkesinambungan antara komponen yang satu maupun komponen lainya dalam interaksi pembelajaran.

Larmer \& Margendoller (2015) dalam kajianya tentang Essentials for Project Based Learning, mengemukakan bahawa pembelajaran berbasis masalah, guru harus merencanakan sebuah program yang fokus pada pengetahuan penting dan konsep yang memenuhi standard perkembangan siswa. Isi dari pembelajaran berbasis masalah juga harus mencerminkan apa yang menjadi pikiran dan tujuan guru untuk memahami tentang suatu topik tertentu, dan siswa harus menemukan isi menjadi signifikan terkait dengan kehidupan dan kepentingan/ kebutuhan mereka sendiri.

Savin-Baden \& Wilkie (2014) dalam kajianya tentang Rethinking the lecture: The application of problem based learning methods to atypical contexts, mengemukakan bahwa Pembelajaran berbasis masalah (PBL) sebagai strategi yang menggunakan stimulus bermasalah bagi siswa untuk mengembangkan dan memperoleh pengetahuan. Siwa disajikan dengan masalah untuk memecahkan dari pada kuliah untuk menyerap. Mahasiswa, bekerja dalam kelompok kecil di ruang kelas, ditantang untuk menerapkan informasi yang dipelajari sebelumnya untuk masalah ini dan mengidentifikasi pengetahuan dan keterampilan mereka kurang akurat memecahkan masalah

Pembelajaran berbasis masalah dapat meningkatkan kualitas dan kuantitas interaksi pembelajaran yang dilakukan oleh guru sebagai tenaga kependidikan, maka profesi guru harus memiliki dan menguasai perencanaan kegiatan belajar mengajar. Kemampuan guru dalam merencanakan dan melaksanakan proses pembelajaran merupakan faktor utama dalam mencapai tujuan pengajaran. Keterampilan merencanakan dan melaksanakan proses belajar mengajar ini sesuatu yang erat kaitanya dengan tugas dan tanggungjawab guru sebagai pengajar.

Menurut Chris W. H. Woo \& Kumar Laxman (2012) dalam penelitianya tentang Countering the Pedagogy of Extremism: Reflective Narratives and Critiques of Problem-Based Learning. International Education Studie, menngemukakan bahwa Pembelajaran berbasis masalah adalah mengajar dan belajar strategi yang menggunakan stimulus bermasalah sebagai sarana siswa memotivasi dan mengarahkan untuk mengembangkan dan memperoleh pengetahuan. Pembelajaran berbasis masalah adalah 
strategi yang biasanya digunakan dengan kelompok-kelompok kecil menghadiri serangkaian sesi.

Hal yang sama yang di ungkapkan oleh Carmen Johama, and Marilyn Clarke (2012) dalam penelitianya tentang Teaching Critical Management Skills: The Role Of Problem-Based Learning, hasil penelitianya memaparkan bahwa pembelajaran berbasis masalah (PBL) sebagai Kendaraan untuk review mengembangkan keterampilan manajemen kritis Dan mempersiapkan Siswa untuk review karir Masa Depan mereka. Secara konsep pembelajaran berbasis masalah dapat membantu siswa untuk berpikir kritis, pendidik khususnya dapat menerapkan pembelajaran berbasis masalah dalam rangka meningkatkan kualitas peserta didik, sehingga kedepanya siswa tidak keget dengan masalah yang dihadapinya.

\section{Evaluasi dan tindaklanjut pembelajaran Fisika berbasis masalah.}

Evaluasi pembelajaran Fisika Berbasis Maasalah di Negeri 1 Soromandi dilaksanakan dengan tujuan untuk mengetahui sampai sejauhmana peserta didik menguasai dan memahami materi pembelajaran Fisika yang sudah diajarkan guru kepada peserta didik. Evaluasi pembelajaran terbagi menjadi tiga bentuk yaitu evaluasi tertulis,lisan, dan perbuatan. Evaluasi tertulis diperoleh dari nilai ulangan harian peserta didik secara tertulis. Evaluasi lisan adalah evaluasi yang diperoleh dengan cara peserta didik diberi pertanyaan secara lisan dan dijawab satu persatu oleh peserta didik.

\section{Penutup}

Keterampilan untuk dapat berpikir secara kritis merupakan keterampilan yang harus dimiliki oleh setiap orang untuk dapat berhasil dalam mengatasi tantangan dan permasalahan di masa kini dan masa yang akan datang. PBL merupakan model pembelajaran yang menggunakan masalah dunia nyata sebagai suatu konteks bagi siswa untuk belajar tentang keterampilan pemecahan masalah dan berpikir kritis untuk memperoleh pengetahuan dan konsep essensial. Model pembelajaran PBL telah terbukti dapat meningkatkan partisipasi, aktivitas, motivasi, dan hasil belajar siswa serta meningkatkan keterampilan berpikir kritis/berpikir tingkat tinggi. Ketersediaan sumber belajar merupakan hal yang sangat penting untuk menerapkan PBL. Pada saat ini, terdapat berbagai sumber belajar yang dapat mendukung penerapan PBL dalam pembelajaran IPA Fisika. Sehingga kini semua bergantung pada guru dan pihak sekolah apakah mereka mau menerapkan PBL guna meningkatkan keterampilan berpikir kritis siswanya. 


\section{Daftar Rujukan}

Abas, Nurhayati, 2000. Pengembangan Perangkat Pembelajaran Matematika Berorientasi Model Pembelajaran Berdasarkan Masalah (Problem Bassed Intruction). Program Studi Pendidikan Matematika Program Pascasarjana. UNESA

Abas, Nurhayati, 2000. Pengembangan Perangkat Pembelajaran Matematika Berorientasi Model Pembelajaran Berdasarkan Masalah (Problem Bassed Intruction). Program Studi Pendidikan Matematika Program Pascasarjana. UNESA

Chris W. H. Woo \& Kumar Laxman, 2012. Countering the Pedagogy of Extremism: Reflective Narratives and Critiques of Problem-Based Learning. International Education Studies. Vol. 6, No. 1; 2013, ISSN 1913-9020 E-ISSN 1913-9039, Published by Canadian Center of Science and Education: URL: http:// dx.doi.org/ 10.5539/ ies.v6n1p46.pdf

Carmen Johama* and Marilyn Clarke, 2012. Teaching critical management skills: the role of problem-based learning. Vol. 17, No.1.

David O'Sullivan and Finn Krewer, 2013. Structured Approach to Project Based Learning using a new type of Learning Management System. Journal Instituto Superior de Engenharia do Porto. david gouveia@virtual-campus.eu

Eviline Siregar, 2010. Teori belajar dan pembelajaran. Ghalia Indonesia: Bogor

Hamalik, O. 2007. Manajemen Pengembangan Kurikulum. Bandung: PT. Rosda Karya.

Ibrahim. 2000. Pembelajaran Berbasis Masalah. http:// www.wordpress.com.

J Contin Educ Nurs, 2017. Using Problem-Based Learning in Staff Development: Strategies for Teaching Registered Nurses and New Graduate Nurses. Journal.

Jodion Siburian, 2010. Panduan Materi Pembelajaran Model Pembelajaran Sains. Revika Aditama: Bandung

Kokom Komalasari, 2013. Pembelajaran Kontekstual konsep dan aplikasi. Revika Aditama: Bandung

Larmer (2015). “Essentials for Project Based Learning”. Journal Buck Institute for Education 18 commercial Blvd. National, CA, USA 94949 ph.415883-0122. $\quad$ http://www.bie.org/ image/ uploads/ useful stuff/ 8Essentials article small file size Oct2012version.pdf.

Muslimin I 2000. Model Pembelajaran Berbasis Masalah. Bandung: Cv Alfabeta

Marthen Kangina, 2002. Fisika Kelas 2 2 SMA. Erlangga

Rusdiana, 2016. Strategi Pengelolaan Pendidikan. Bandung: Rosdakarya

Sugiyono. 2014. Metode Penelitian Pendidikan. Bandung: Alfabeta 
Satoru Takahashi, Eisuke Saito, 2015. " Unraveling the process and meaning of problem-based learning experiences". No 693-706. Email:Takahashi.Satoru@jica.go.jp.

Silver, CEH. 2004. Problem -based learning: What and how do students learn?". Education psychology Review, Vol. 16, No 3,. http:// kanagawa.Iti.cs.cmu.edu/ sites/ default/ files/ HmeloSilver.pdf

Savin-Baden \& Wilkie, 2014. Rethinking the lecture: The application of problem based learning methods to atypical contexts.

Ward JD, Stephens, S, \& Lee. 2016. A Reviuw Of Problem Based Learning. Journal of family and Consusmer Science Education, Vol 20. No 1. 
Jurnal Lentera

Jurnal Studi Pendidikan

136|Edisi 1 No 2 Juli 2019 